\title{
Acute Stroke due to Electrocution: Uncommon or Unrecognized?
}

\author{
Laxmi Kokatnur ${ }^{1,2}$ and Mohan Rudrappa ${ }^{1,2}$ \\ ${ }^{1}$ Louisiana State University Health Sciences Center Shreveport, 1501 Kings Hwy, Shreveport, LA 71104, USA \\ ${ }^{2}$ Overton Brooks VA Medical Center, 510 E Stoner Ave, Shreveport, LA 71101, USA \\ Correspondence should be addressed to Laxmi Kokatnur; drlaxmisk@gmail.com
}

Received 29 August 2016; Accepted 10 November 2016

Academic Editor: Andreas K. Demetriades

Copyright ( 92016 L. Kokatnur and M. Rudrappa. This is an open access article distributed under the Creative Commons Attribution License, which permits unrestricted use, distribution, and reproduction in any medium, provided the original work is properly cited.

\begin{abstract}
The growing dependence on electricity in our daily lives has increased the incidence of electrocution injuries. Although several neurological injuries have been described previously, acute stroke due to electrocution is rare. Our patient, a previously healthy man, was electrocuted after he grabbed a "live" high-voltage wire. Although he was hemodynamically stable, he remained confused with language defects. MRI of the brain showed acute stroke in the bilateral anterior cerebral artery territory and watershed regions of the left middle cerebral artery territory. MR angiogram incidentally showed A1 segment aplasia of the right anterior cerebral artery. Electrocution is known to cause vasospasm leading to end-organ damage similar to that seen in stroke. In our patient, vasospasm of the left anterior circulation likely led to watershed infarcts in the left parietal lobe and bilateral frontal lobes. Due to aplasia of the Al segment on the right side, perfusion to both frontal lobes was solely from the left anterior cerebral artery.
\end{abstract}

\section{Introduction}

Electricity played a crucial role in building modern civilization, and humans have paid the price for it. On an average, 411 people will be electrocuted every year [1]. Despite improvements in overall safety measures, this number is likely to increase as we depend more on electricity in every aspect of our lives. The severity of injury depends on the type and strength of current and ranges from a barely perceptible tingling sensation to instant death. Even though several neurological injuries have been described before, acute stroke due to electrocution is only reported in a handful of cases. This underreporting might be due to uncommon occurrence or under recognition. We present a case of acute stroke due to electrocution along with a review of the literature to increase awareness of this rare condition among medical professionals. The early diagnosis and treatment of this condition will have therapeutic implications.

\section{Case Presentation}

A 38-year-old white male was found down in the field after he reportedly grabbed a "live" electrical wire. On the way to the local hospital, he regained consciousness but remained confused thereafter. He had sustained second-degree burns at the entry wound in the right palm and had a small exit wound in the right foot. Ecchymosis was also noted on right side of the body over the knee, thigh, and shoulder. A pan CT scan of the body did not reveal any major abnormality, including fractures. He remained hemodynamically stable but was pleasantly confused with a nonfocal neurological examination. A CT scan of the brain showed multiple hypodensities in the left parietal region and frontal region bilaterally. All serology labs were normal except total creatinine kinase levels, which peaked at $1100 \mathrm{U} / \mathrm{L}$. Hence, he was transferred to the burn unit in our hospital for further management of burns with rhabdomyolysis. On examination, he was a pleasant gentleman with complete amnesia of the inciting event. He was alert but disoriented to all spheres. Most of the responses were limited to either head nodding or a few words associated with tangentiality and paraphasia. Repetition was impaired, but comprehension was preserved for simple commands. The cranial nerves and motor and sensory systems were clinically normal except limitation of the right arm's movement due to pain. MRI of the brain using 1.5 Tesla MRI machine showed multiple areas of diffusion restriction 


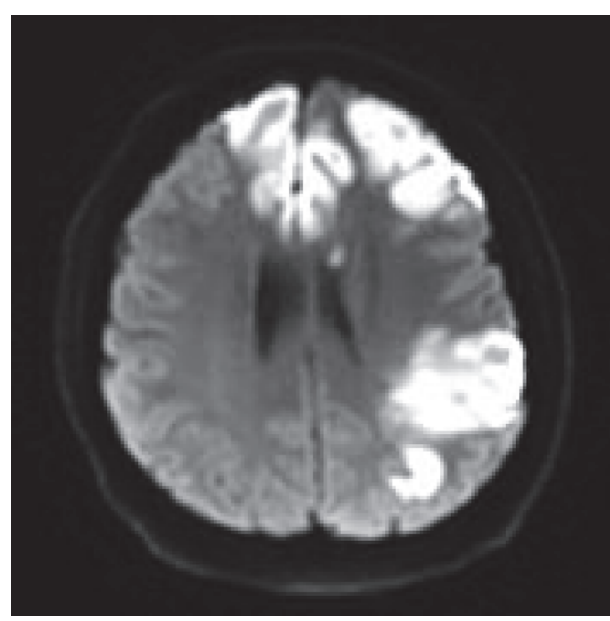

(a)

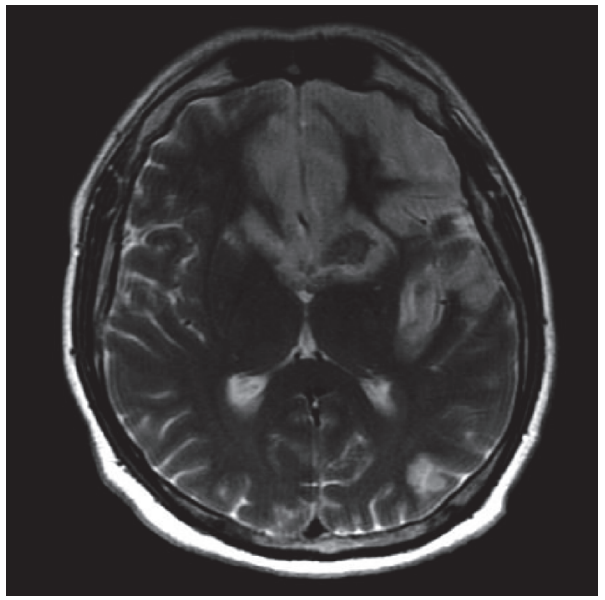

(c)

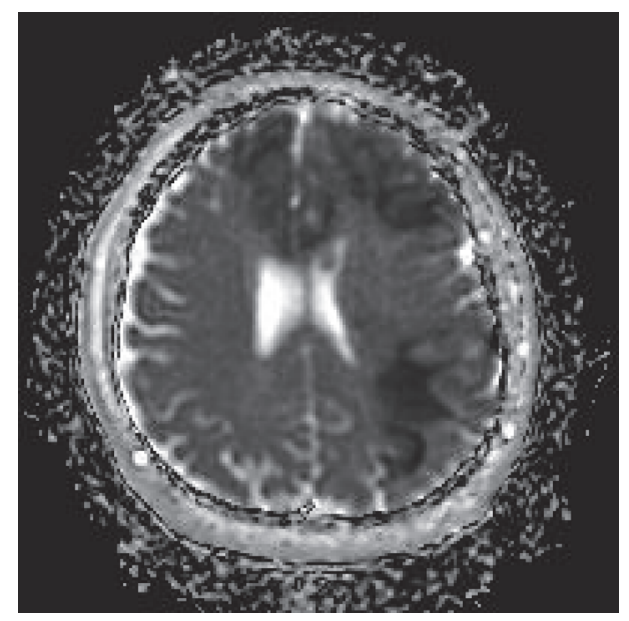

(b)

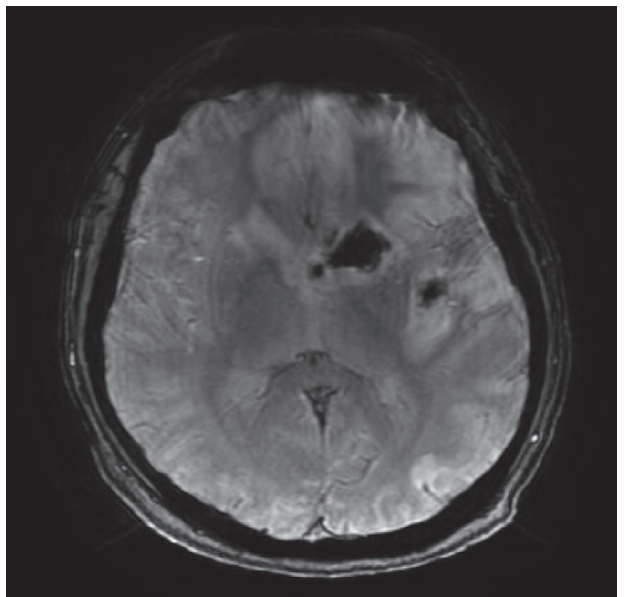

(d)

FIGURE 1: Selected images of MRI of brain. ((a) and (b)) (DWI/ADC) image showing restriction diffusion in bilateral medial frontal lobes and watershed areas in frontal and temporal lobes. (c) T2-weighted image showing hyperintensities in basal ganglia (recurrent artery of Heubner). (d) SWI sequence showing hemorrhagic changes in left basal ganglia and insula.

in the bilateral medial frontal lobe and bilateral basal ganglia along with watershed areas in the left frontal and temporal regions (Figure 1). Susceptibility-weighted images showed hemorrhage in the left basal ganglia and insula (Figure 1). T2weighted images showed hyperintensity in the corresponding regions. MR angiogram did not reveal any filling defect or obvious vasospasm but showed aplastic A1 segment of the right anterior cerebral artery (Figure 2). Based on these findings, acute stroke was diagnosed, likely due to vasospasm of the left anterior cerebral circulation due to electrocution. As the patient had presented 3 days after the injury and had shown clinical improvement, it was hypothesized that vasospasm of cerebral vessels might have been resolved when MR angiogram was performed. No hypotension in the field was reported by the first responders and no hypotension was documented during the initial intensive care unit stay at the outside hospital and telemetry monitoring at our center. Also, there was no evidence of end-organ injury due to hypotension induced hypoperfusion arguing against hypotension induced watershed cerebral infarction. Due to aplasia of the right A1 segment, both frontal lobes were supplied by the anterior cerebral artery and vasospasm of the left anterior cerebral circulation might have led to both frontal lobe infarcts along with watershed infarcts of the left middle cerebral artery territory.

An extensive work-up did not reveal any other risk factors for stroke. Transthoracic echocardiogram showed normal structural and functional heart without any intracardiac thrombus; vegetation and bubble study did not show any right to left shunt. Telemetry cardiac monitoring also failed to detect any cardiac arrhythmia. MRA neck did not show any evidence of carotid or vertebral artery disease. The patient's family denied that the patient had any preexisting medical or surgical conditions, including a substance abuse problem. He was an anthropology graduate working as a stunt man for movies and reported being healthy before this event. Despite extensive interviews, the circumstances of the electrocution could not be elucidated, except that he was barefoot at the 


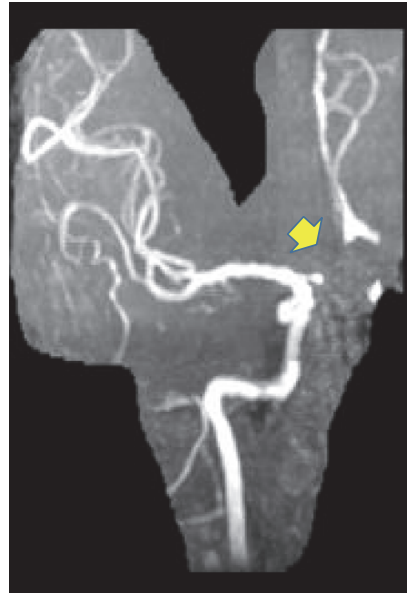

(a)

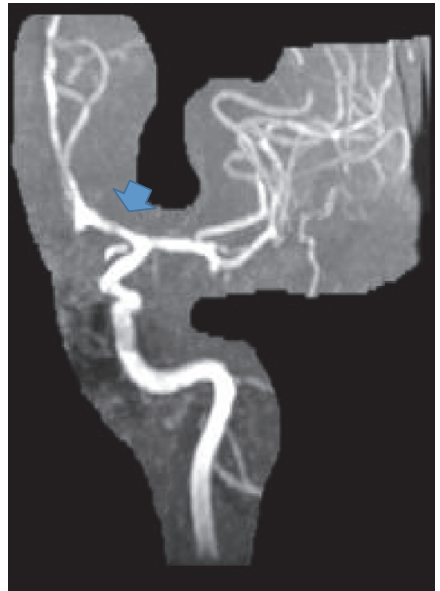

(b)

Figure 2: Selected images of MR angiogram. (a) Aplastic A1 segment of right ACA (yellow arrow). (b) Normal A1 segment of left ACA (blue arrow) supplying both frontal lobes.

time of the accident and it was a high-voltage electrical wire. People visiting a local church found him confused on the ground and called for emergency medical services. With supportive treatment, the patient's overall condition improved with some residual language defects. The mild rhabdomyolysis improved after hydration. The entry and exit electric burn wounds responded to local wound care. He was transferred to the neurorehabilitation center for further management and is reported to be recovering well.

\section{Discussion}

Electricity is the flow of electrons through a conductor and is the main source of energy in the 21st century. Voltage is the force responsible for the flow and is measured in volts. Current is the strength of the flow and is measured in amperes. Direct current (DC) flows in only one direction, but alternating current (AC) changes its direction based on the set frequency. Electricity is transported from the production site as AC at a high voltage of $230-700 \mathrm{kV}$ and is gradually reduced to $220-120 \mathrm{~V}$ using transformers before it reaches domestic customers. The severity of electrocution injuries depends on the strength of the current and duration of contact. While 1 milliamp ( $\mathrm{mA}$ ) barely causes a tingling sensation, $20 \mathrm{~mA}$ can paralyze respiratory muscles. Electrocution with more than 2 amps of current causes significant internal organ and cardiac damage, leading to sudden death [1]. Most electrocution injuries occur in domestic settings with lowvoltage current. They rarely require medical attention and are underreported. Injuries from high-voltage electrocution (more than 600 volts) account for $3 \%-5 \%$ of admissions to burn units and $7 \%$ of all work-related fatalities $[1,2]$.

After electrocution, the tissues sustain injuries based on their resistance to the flow of current. The nervous system, blood vessels, and mucous membrane are more prone to injuries as they offer less resistance. Bones, fat, and tendons offer more resistance, but they generate more heat and suffer
TABLE 1: Neurological injuries caused by electrocution.

\begin{tabular}{|c|c|c|}
\hline $\begin{array}{l}\text { Type of nervous } \\
\text { system }\end{array}$ & Immediate & Delayed \\
\hline $\begin{array}{l}\text { Central nervous } \\
\text { system }\end{array}$ & $\begin{array}{l}\text { Confusion } \\
\text { Loss of consciousness } \\
\text { Amnesia } \\
\text { Acute stroke } \\
\text { Seizure } \\
\text { Headache } \\
\text { Focal brain necrosis } \\
\text { Transection of spinal } \\
\text { cord } \\
\text { Rupture of aneurysm }\end{array}$ & $\begin{array}{l}\text { Transverse myelitis } \\
\text { Amyotrophic } \\
\text { lateral sclerosis } \\
\text { Ascending } \\
\text { paralysis } \\
\text { Personality } \\
\text { changes } \\
\text { Delayed brain } \\
\text { atrophy }\end{array}$ \\
\hline $\begin{array}{l}\text { Peripheral nervous } \\
\text { system }\end{array}$ & Nerve palsy & Neuropathies \\
\hline $\begin{array}{l}\text { Autonomic nervous } \\
\text { system }\end{array}$ & $\begin{array}{l}\text { Raynaud } \\
\text { phenomenon } \\
\text { Horner's syndrome } \\
\text { Keraunoparalysis }\end{array}$ & $\begin{array}{l}\text { Complex regional } \\
\text { pain syndrome }\end{array}$ \\
\hline
\end{tabular}

thermal injury. AC causes tetanic contraction of muscles and the victim is thrown away, breaking the circuit. In contrast, DC of the same strength causes continuous contraction of muscles, making the victim hold on to the source of the current, leading to further electrocution $[12,13]$. The nervous system, by virtue of its electrochemical properties, offers the least resistance to the flow of current and hence it is commonly involved in electrocution injuries. Most patients show transient confusion due to alteration of the electrical potential in the brain, which resolves with time. If the brainstem is directly involved, even a low-strength current can cause death due to the involvement of cardiorespiratory centers. Even though most recover from the initial injury, several delayed-onset symptoms of electrocution have also been described [12]. The spectrum of neurological injuries due to electrocution is noted in Table 1. 
TABLE 2: Published case reports of acute stroke due to electrocution.

\begin{tabular}{|c|c|c|c|c|c|c|c|c|}
\hline $\begin{array}{l}\text { Author, } \\
\text { year }\end{array}$ & $\begin{array}{l}\text { Age } \\
\text { Sex }\end{array}$ & Voltage & $\begin{array}{c}\text { Entry } \\
\text { site/exit site }\end{array}$ & $\begin{array}{l}\text { CT head } \\
\text { findings }\end{array}$ & $\begin{array}{l}\text { MRI brain } \\
\text { findings }\end{array}$ & Angiogram ${ }^{*}$ & Follow-up ${ }^{* *}$ & $\begin{array}{l}\text { Other key } \\
\text { findings }\end{array}$ \\
\hline $\begin{array}{l}\text { Singh Jain } \\
\text { et al., } 2015 \\
\text { [3] }\end{array}$ & $\begin{array}{c}40 \\
\text { Male }\end{array}$ & $\begin{array}{l}\text { High } \\
11000 \mathrm{~V}\end{array}$ & $\begin{array}{c}\text { Right } \\
\text { arm/axilla }\end{array}$ & $\begin{array}{l}\text { Bilateral, } \\
\text { cerebellar, } \\
\text { and left } \\
\text { occipital } \\
\text { hypodensity }\end{array}$ & $\begin{array}{l}\text { Bilateral, } \\
\text { cerebellar, and } \\
\text { left occipital } \\
\text { stroke }\end{array}$ & Normal & $\begin{array}{l}\text { Symptoms } \\
\text { improved }\end{array}$ & $18 \%$ burns \\
\hline $\begin{array}{l}\text { Bell et al., } \\
2014 \text { [4] }\end{array}$ & $\begin{array}{c}32 \\
\text { Male }\end{array}$ & $\begin{array}{c}\text { High } \\
50000 \mathrm{~V} \\
\text { Taser gun }\end{array}$ & $\mathrm{NP} / \mathrm{NP}$ & $\begin{array}{l}\text { Left MCA } \\
\text { territory } \\
\text { infarct }\end{array}$ & $\begin{array}{c}\text { Left MCA } \\
\text { territory } \\
\text { ischemic stroke }\end{array}$ & $\begin{array}{l}\text { Distal M1 and } \\
\text { proximal M2 left } \\
\text { middle cerebral } \\
\text { artery filling } \\
\text { defect }\end{array}$ & NP & \\
\hline $\begin{array}{l}\text { Kim et al., } \\
2014 \text { [5] }\end{array}$ & $\begin{array}{c}52 \\
\text { Male }\end{array}$ & $\begin{array}{l}\text { Low } \\
220 \mathrm{~V}\end{array}$ & $\begin{array}{c}\text { Right } \\
\text { hand/left } \\
\text { hand }\end{array}$ & & $\begin{array}{c}\text { Left MCA } \\
\text { territory } \\
\text { ischemic stroke }\end{array}$ & $\begin{array}{c}\text { Focal stenosis of } \\
\text { left MCA, left } \\
\text { proximal ACA, } \\
\text { and proximal } \\
\text { basilar artery }\end{array}$ & $\begin{array}{l}\text { Symptoms } \\
\text { resolved }\end{array}$ & $\begin{array}{l}\text { Radial nerve } \\
\text { neuropathy }\end{array}$ \\
\hline $\begin{array}{l}\text { Jain et al., } \\
2014[6]\end{array}$ & $\begin{array}{c}55 \\
\text { Male }\end{array}$ & $\begin{array}{l}\text { High } \\
66000 \mathrm{~V}\end{array}$ & $\mathrm{NP} / \mathrm{NP}$ & NP & $\begin{array}{l}\text { Left cerebellum } \\
\text { ischemia stroke } \\
\text { with mass effect }\end{array}$ & $\begin{array}{c}\text { Diffuse narrow- } \\
\text { ing/vasospasm } \\
\text { of left vertebral } \\
\text { artery }\end{array}$ & $\begin{array}{l}\text { Symptoms } \\
\text { improved. } \\
\text { Vasospasm } \\
\text { resolved at } 6 \\
\text { months }\end{array}$ & \\
\hline $\begin{array}{l}\text { Johl et al., } \\
2012 \text { [7] }\end{array}$ & $\begin{array}{c}43 \\
\text { Male }\end{array}$ & $\begin{array}{l}\text { Low } \\
440 \mathrm{~V}\end{array}$ & Scalp/left foot & NP & $\begin{array}{c}\text { Bilateral } \\
\text { medullary } \\
\text { pyramids and } \\
\text { pons }\end{array}$ & NP & $\begin{array}{l}\text { Symptoms } \\
\text { improved. } \\
\text { MRI changes } \\
\text { resolved }\end{array}$ & $\begin{array}{l}\text { Spinal card } \\
\text { infarction }\end{array}$ \\
\hline $\begin{array}{l}\text { Chen et } \\
\text { al., } 2012 \\
{[8]}\end{array}$ & $\begin{array}{c}62 \\
\text { Female }\end{array}$ & $\begin{array}{l}\text { Low } \\
110 \mathrm{~V}\end{array}$ & Left hand/NP & NP & $\begin{array}{l}\text { Left paramedian } \\
\text { pons ischemic } \\
\text { stroke }\end{array}$ & $\begin{array}{l}\text { Narrowing of } \\
\text { proximal basilar } \\
\text { artery, bilateral } \\
\text { distal vertebral } \\
\text { artery, and } \\
\text { MCA likely due } \\
\text { to thrombosis }\end{array}$ & $\begin{array}{l}\text { Symptoms } \\
\text { resolved. } \\
\text { Stenosis } \\
\text { progressed }\end{array}$ & $\begin{array}{l}\text { Protein C } \\
\text { deficiency }\end{array}$ \\
\hline $\begin{array}{l}\text { Verma et } \\
\text { al., } 2014 \\
\text { [9] }\end{array}$ & $\begin{array}{c}30 \\
\text { Male }\end{array}$ & $\begin{array}{l}\text { Low } \\
240 \mathrm{~V}\end{array}$ & $\mathrm{NP} / \mathrm{NP}$ & $\begin{array}{l}\text { Right MCA } \\
\text { infarct with } \\
\text { mass effect }\end{array}$ & NP & NP & $\begin{array}{l}\text { Symptoms } \\
\text { improved. } \\
\text { Mass effect } \\
\text { resolved }\end{array}$ & $\begin{array}{l}\text { Acute } \\
\text { myocardial } \\
\text { infarction }\end{array}$ \\
\hline $\begin{array}{l}\text { Huan-Jui } \\
\text { et al., } 2010 \\
{[10]}\end{array}$ & $\begin{array}{c}50 \\
\text { Male }\end{array}$ & $\begin{array}{l}\text { Low } \\
110 \mathrm{~V}\end{array}$ & $\begin{array}{c}\text { Both } \\
\text { hands/NP }\end{array}$ & Normal & $\begin{array}{c}\text { Right } \\
\text { frontotemporal } \\
\text { area, basal } \\
\text { ganglia, and } \\
\text { corona radiate } \\
\text { stroke }\end{array}$ & $\begin{array}{c}\text { Segmental } \\
\text { narrowing of } \\
\text { siphon of right } \\
\text { internal carotid } \\
\text { artery and M1 } \\
\text { segment of } \\
\text { middle cerebral } \\
\text { artery }\end{array}$ & $\begin{array}{l}\text { Symptoms } \\
\text { did not } \\
\text { improve. } \\
\text { Vasospasm } \\
\text { resolved }\end{array}$ & $\begin{array}{l}\text { TPA was given. } \\
\text { Vasospasm } \\
\text { improved with } \\
\text { intra-arterial } \\
\text { nimodipine }\end{array}$ \\
\hline $\begin{array}{l}\text { Kamyar } \\
\text { and Trob, } \\
2009[11]\end{array}$ & $\begin{array}{c}28 \\
\text { Male }\end{array}$ & $\begin{array}{l}\text { Low } \\
220 \mathrm{~V}\end{array}$ & $\begin{array}{l}\text { Both } \\
\text { hands/left } \\
\text { foot }\end{array}$ & Normal & $\begin{array}{c}\text { Mesial occipital } \\
\text { bilateral } \\
\text { infarction }\end{array}$ & NP & $\begin{array}{l}\text { Symptoms } \\
\text { improved }\end{array}$ & $\begin{array}{l}\text { Cardiac arrest } \\
\text { for } 10 \text { min. } \\
\text { Cardiogenic- } \\
\text { ischemic } \\
\text { encephalopathy }\end{array}$ \\
\hline
\end{tabular}

NP: not reported. $*$ refers to either CT MR or digital subtraction angiogram. $* *$ indicates that most cases report short follow-up period.

Acute stroke due to electrocution is uncommon and has been described in only nine cases in the English literature to the best of our knowledge. The salient features of these cases are summarized in Table 2. As the available evidence is from case reports, there is paucity of knowledge regarding the pathophysiology, clinical features, treatment, and outcomes of stroke due to electrocution. Most cases are reported in young males involving low-voltage current. Interestingly, acute stroke can occur even when the central nervous system is not in the direct path of the current, as seen in our patient.

Blood vessels, due to their high water content, can transmit electric current easily to distant sites and cause metastatic 
injuries. In animal models, direct electrical stimulation of cerebral vessels can cause vasospasm and this effect has been seen at distant sites [14]. In a study looking at vascular injuries due to electrocution in humans, vasospasm was seen in 8 of 12 patients on angiogram [15]. Electrostatic energy in blood vessels can initiate vascular mediopathy and/or intravascular coagulation even when the surrounding tissues appear to be normal [8]. In fact, electricity is used for thrombus generation in animal models when studying carotid artery clots [16]. Acute stroke is also described in electric injury due to lightning [17].

All reported cases were treated as per standard guidelines for the management of acute stroke. Thrombolysis was administered in one patient with no benefit. Later, intraarterial nimodipine showed a favorable response [10]. Most cases showed clinical improvement, some with complete radiological resolution. The interesting but unfortunate finding of A1 segment aplasia contributed to significant bilateral frontal lobe injury in our patient. Al segment aplasia is an uncommon developmental defect seen in approximately $2 \%$ of cases of stroke on angiograms [18]. Bilateral frontal lobe stroke due to Al segment aplasia has been reported in only three case reports [19].

\section{Conclusion}

Neurological injuries are common after electrocution injuries. Physicians should be wary of neurological injuries including acute stroke, even when the nervous system does not fall in the path of the current. Timely neuroimaging is helpful and if vasospasm is noted on an angiogram, intra-arterial nimodipine can be considered. The prognosis is excellent with supportive treatment.

\section{Competing Interests}

The authors, Dr. Laxmi Kokatnur and Dr. Mohan Rudrappa, declare that there are no competing interests regarding the publication of this paper.

\section{References}

[1] S. Kisner and V. Casini, "Epidemiology of electrocution fatalities," Worker Death by Electrocution, A Summary of Niosh Surveillance and Investigative Findings, Department of Health and Human Resource, Washington, DC, USA, no. 98-131, pp. 919, May 1998, http://www.cdc.gov/niosh/docs/98-131/pdfs/98131.pdf.

[2] A. A. Mohammadi, M. Amini, D. Mehrabani, Z. Kiani, and A. Seddigh, "A survey on 30 months electrical burns in Shiraz University of Medical Sciences Burn Hospital," Burns, vol. 34, no. 1, pp. 111-113, 2008.

[3] R. Singh Jain, S. Kumar, D. T. Suresh, and R. Agarwal, "Acute vertebrobasilar ischemic stroke due to electric injury," The American Journal of Emergency Medicine, vol. 33, no. 7, pp. $992-$ 992.e6, 2015.

[4] N. Bell, M. Moon, and P. Dross, "Cerebrovascular accident (CVA) in association with a Taser-induced electrical injury," Emergency Radiology, vol. 21, no. 2, pp. 211-213, 2014.
[5] H. M. Kim, Y. Ko, J. S. Kim, S. H. Lim, and B. Y. Hong, "Neurological complication after low-voltage electric injury: a case report," Annals of Rehabilitation Medicine, vol. 38, no. 2, pp. 277-281, 2014.

[6] R. S. Jain, P. K. Gupta, R. Handa, K. Nagpal, S. Prakash, and R. Agrawal, "Vertebrobasilar territory ischemic stroke after electrical injury: delayed sequelae," Journal of Stroke and Cerebrovascular Diseases, vol. 23, no. 6, pp. 1721-1723, 2014.

[7] H. K. Johl, A. Olshansky, S. R. Beydoun, and R. A. Rison, "Cervicothoracic spinal cord and pontomedullary injury secondary to high-voltage electrocution: a case report," Journal of Medical Case Reports, vol. 6, article 296, 2012.

[8] W.-H. Chen, C. Chui, C.-C. Lui, and H.-L. Yin, "Ischemic stroke after low-voltage electric injury in a diabetic and coagulopathic woman," Journal of Stroke and Cerebrovascular Diseases, vol. 21, no. 8, pp. 913.el-913.e4, 2012.

[9] G. C. Verma, G. Jain, A. Wahid et al., "Acute Ischaemic stroke and acute myocardial infarction occurring together in domestic low-voltage (220-240V) electrical injury: a rare complication," Journal of Association of Physicians of India, vol. 62, no. 7, pp. 620-623, 2014.

[10] Y. Huan-Jui, L. Chih-Yang, L. Huei-Yu, and C. Po-Chih, "Acute ischemic stroke in low-voltage electrical injury: a case report," Surgical Neurology International, vol. 1, no. 1, p. 83, 2010.

[11] R. Kamyar and J. D. Trobe, "Bilateral mesial occipital lobe infarction after cardiogenic hypotension induced by electrical shock," Journal of Neuro-Ophthalmology, vol. 29, no. 2, pp. 107$110,2009$.

[12] A. C. Koumbourlis, "Electrical injuries," Critical Care Medicine, vol. 30, no. 11, pp. S424-S430, 2002.

[13] J. A. Martinez, T. Nguyen, and K. J. Buechter, "Electrical Injuries," Southern Medical Journal, vol. 93, no. 7-12, pp. 1165$1168,2000$.

[14] F. A. Echlin, "Vasospasm and focal cerebral ischemia an experimental study," Archives of Neurology \& Psychiatry, vol. 47, no. 1, pp. 77-96, 1942.

[15] J. L. Hunt, W. F. McManus, W. P. Haney et al., "Vascular lesions in acute electric injuries," Journal of Trauma-Injury, Infection \& Critical Care, vol. 14, no. 6, pp. 461-473, 1974.

[16] A. Kusada, N. Isogai, and B. C. Cooley, "Electric injury model of murine arterial thrombosis," Thrombosis Research, vol. 121, no. 1, pp. 103-106, 2007.

[17] M. Cherington, P. R. Yarnell, and S. F. London, "Neurologic complications of lightning injuries," Western Journal of Medicine, vol. 162, no. 5, pp. 413-417, 1995.

[18] G. Makowicz, R. Poniatowska, and M. Lusawa, "Variants of cerebral arteries-anterior circulation," Polish Journal of Radiology, vol. 78, no. 3, pp. 42-47, 2013.

[19] M. Krishnan, S. Kumar, S. Ali, and R. S. Iyer, "Sudden bilateral anterior cerebral infarction: unusual stroke associated with unusual vascular anomalies," Postgraduate Medical Journal, vol. 89, no. 1048, pp. 120-121, 2013. 


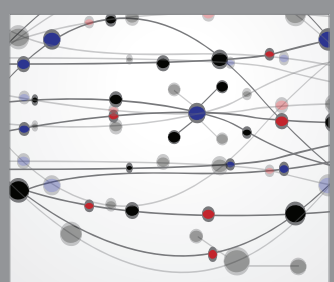

The Scientific World Journal
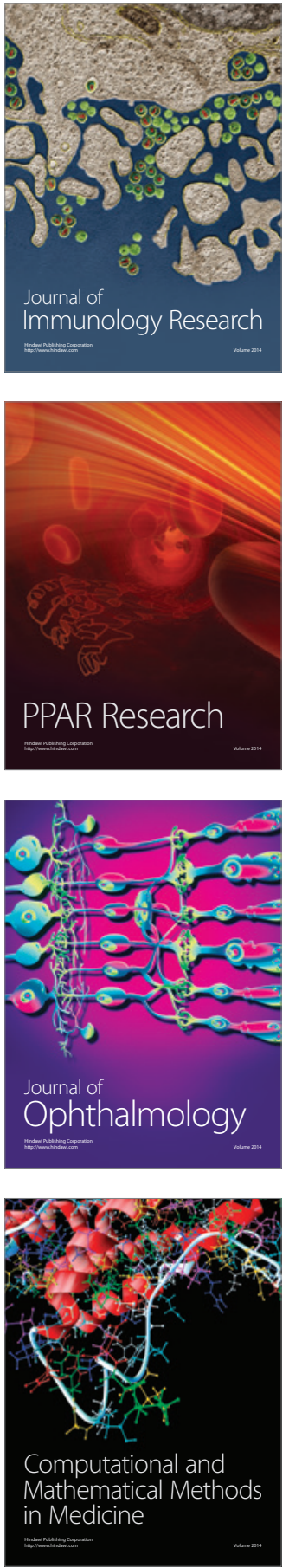

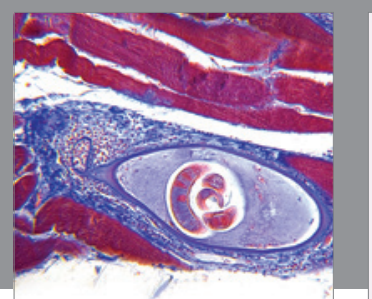

Gastroenterology Research and Practice

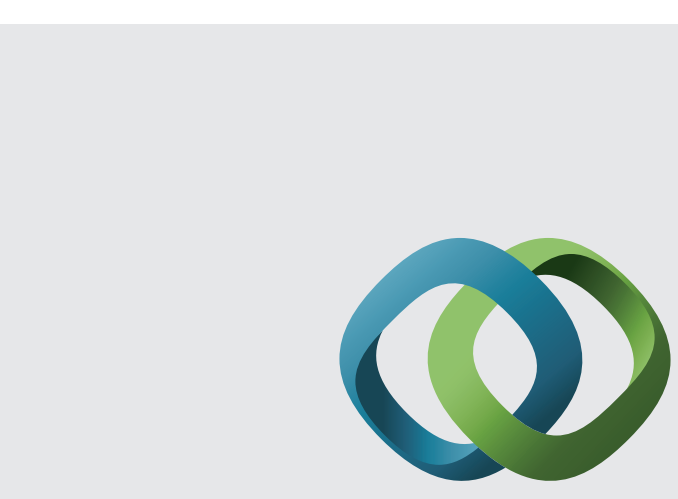

\section{Hindawi}

Submit your manuscripts at

http://www.hindawi.com
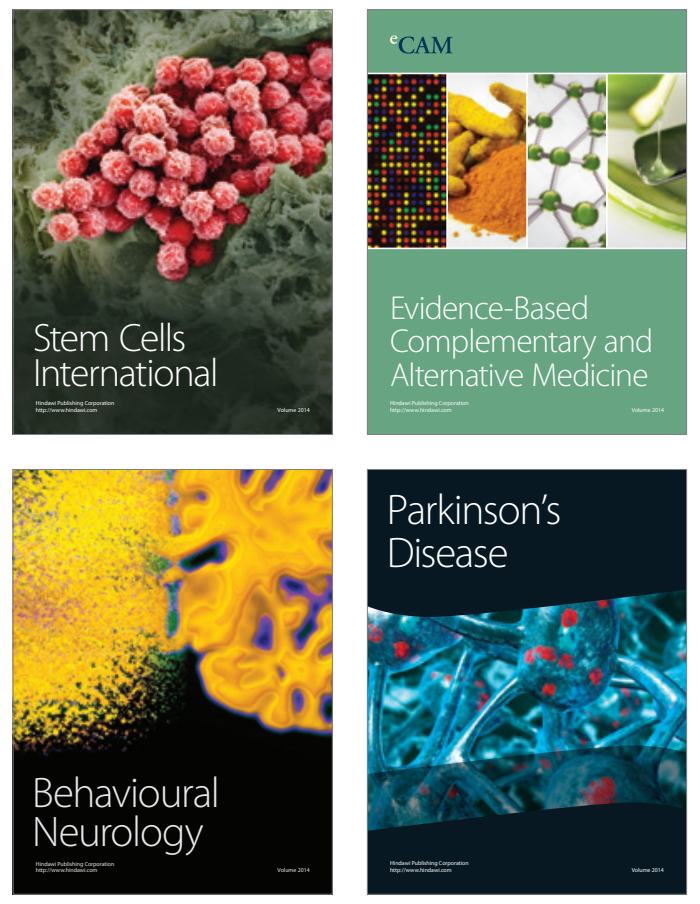
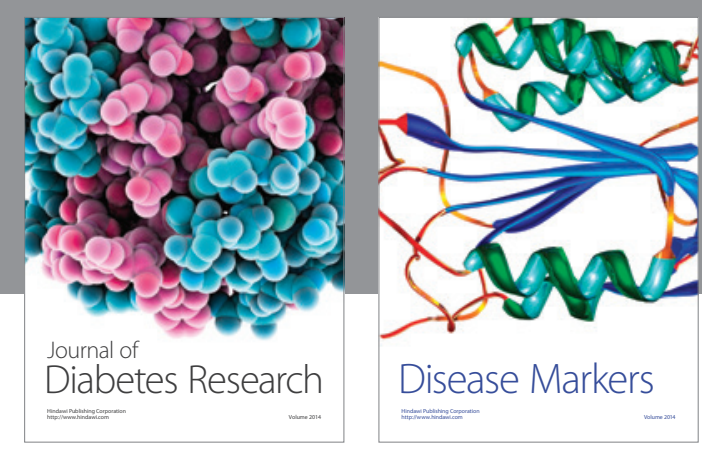

Disease Markers
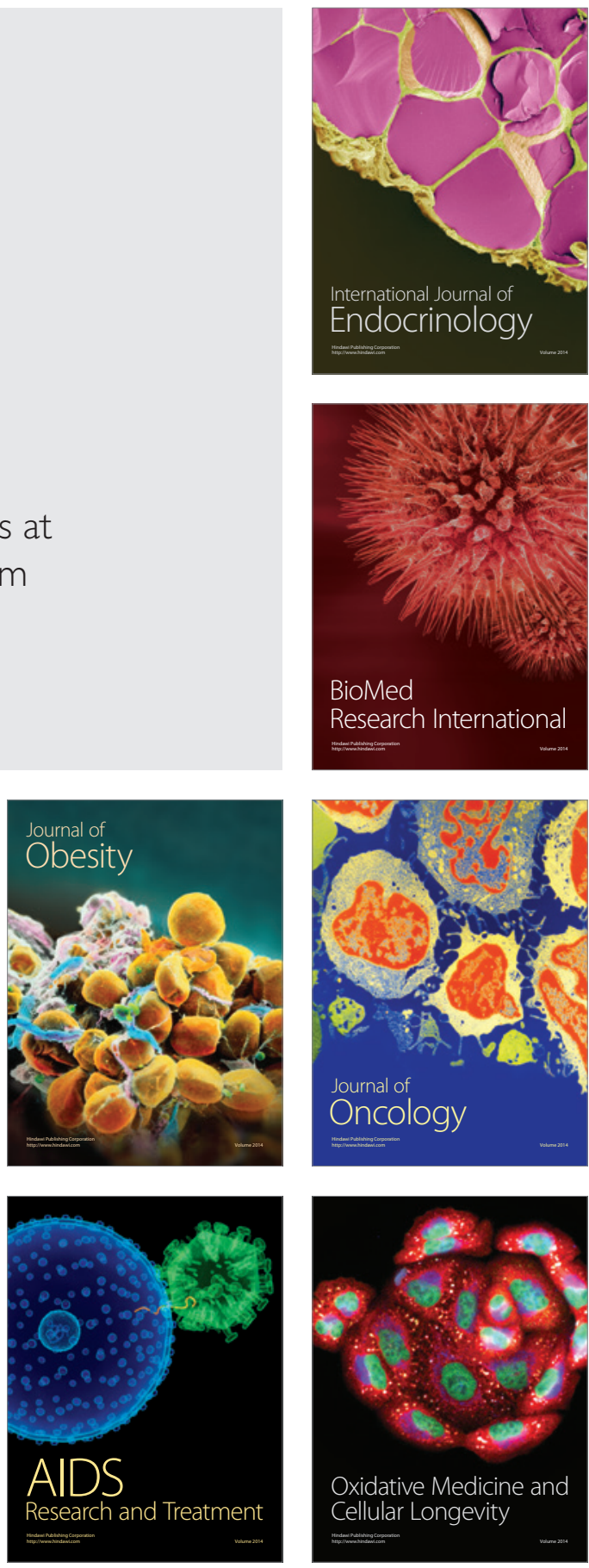